\title{
Public Policy Fundamentals for Sustainable and Inclusive Growth
}

\author{
Ijaz Nabi"
}

\begin{abstract}
Pakistan has seen strong economic growth in recent years accompanied by a reduction in poverty. However, growth has been concentrated, which has meant that regional and inter-personal disparities are on the rise. In a contestable political environment, this casts a shadow on the sustainability of high growth. The budget, a corrective instrument, has been subject to boom and bust cycles because of rigid claims, poor tax effort and external shocks, rendering it ineffective in addressing long term priorities. This paper argues that robust budgets for sustained and inclusive growth require government programs to be credible (monitoring and evaluation and public information) and cost effective (streamlined budget cycle, public-private partnerships); this will help increase citizen willingness to pay for public programs via improved tax compliance.
\end{abstract}

JEL Classification: E22, E23, O43

Keywords: Pakistan, Budget, Growth

\section{A. Sustainable and Inclusive Growth in South Asia and in Pakistan}

South Asian economies have seen robust growth in the last 7 years (2001-2007, Figure-1). The big three, India, Pakistan and Bangladesh, registered average growth of 5.5 percent or more; 2007 real GDP growth was, on average, 1 percentage point higher. Pakistan, as a result of policy reform and a more favorable external environment, finally emerged out of the doldrums of the 1990's to get back to its historical trend growth rate of 6 percent.

\footnotetext{
* Sector Manager, Economic Policy, South Asia Region, World Bank, Washington DC.
} 


\section{South Asia's Promising Growth I:}

Figure 1: Real GDP growth in South Asia has been impressive, especially so in the recent past

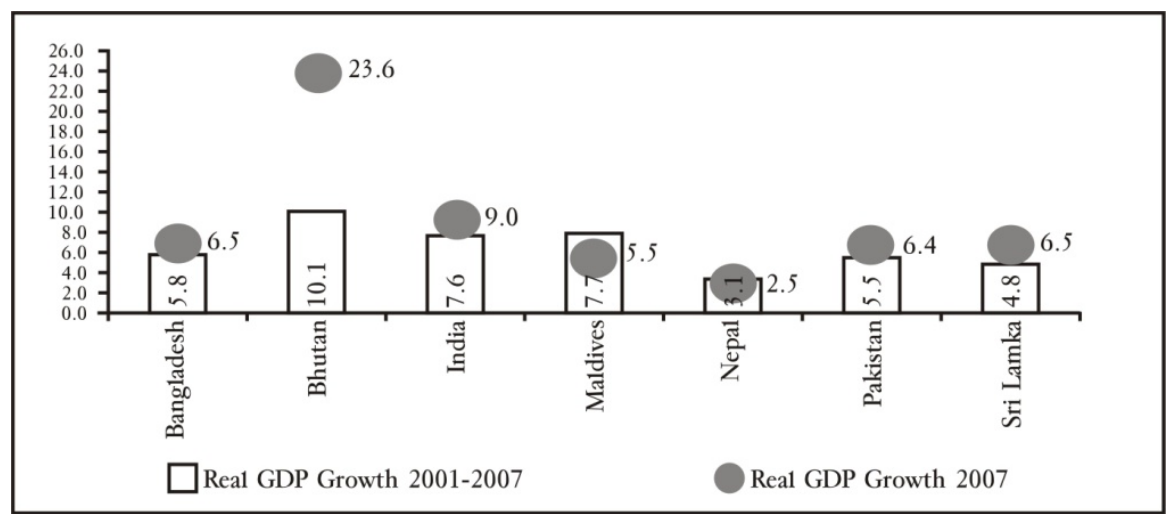

Growth was all the more impressive, since it was accompanied by a reduction in poverty (Figure-2). In India, Bangladesh and Nepal, poverty fell by 10 percentage points. Even though the incidence of poverty in Pakistan shows an increase compared to the 1990's, recovery of growth since 2002 has had a sharp poverty reducing impact. The most recent poverty survey of 2004-5 shows a decline of 10 percentage points compared to 2000-2001.

\section{South Asia's Promising Growth II:}

Figure 2: Poverty (head count index) in South Asia is declining, more so in recent years

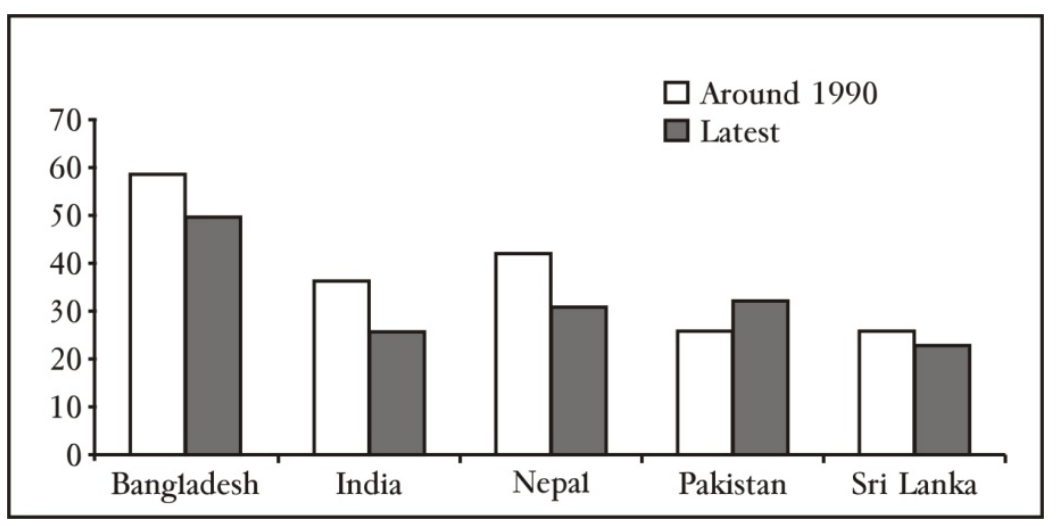

This promising growth performance has encouraged analysts to project even higher growth rates in the coming decade -7 to 10 percent 
- and argue that this will result in the highly desirable objective of complete elimination of poverty in our lifetime ${ }^{8}$. Of course, the recent oil and food price shocks were not taken into account in constructing these positive scenarios.

It is well understood that such desirable outcomes are predicated on movements on many structural dimensions, the most critical is rising inequality across income groups and across regions. In India, average income per capita in the four richest southern states (Kerala, Tamil Nadu, Andhra Pradesh and Karnataka) is nearly three times the income per capita of the largest two northern states (UP and Bihar), and with much higher GDP growth rates, the Southern states are poised to gallop ahead even faster. Poverty outcomes are similarly differentiated. The two northern states have poverty rates ( 38 percent) that are twice the rate in the four southern states. In Pakistan's Punjab, poverty incidence in Southern Punjab (40 percent) is substantially higher than in the Northern and Central districts (30 and 32 percent respectively).

Large geographical differences in income growth and poverty outcomes are the undesirable features of South Asia's growth performance and, in an increasingly contestable political environment, cast a shadow on the sustainability of rapid economic growth over long periods of time.

This paper reviews the structural imbalances that need to be addressed for sustainable and inclusive growth (Section B) and points out the centrality of the budget as an instrument to address the imbalances. It then (Section C) argues that the budget has been unable to address medium term development priorities because of its boom and bust cycles. Those cycles are best broken through a greater willingness by citizens to pay for public programs, but that will happen when there is greater citizen buy-in of public programs and the programs are more efficiently administered to make the tax rupee go further (Section D).

\section{B. The Structural Imbalances that Need to be Addressed for High and Inclusive Growth}

Sustained high growth is also predicated on improvement in the quality of the work force and infrastructure in order to sustain productivity growth in manufacturing and services. On these dimensions, comparisons with East Asia show that all South Asian economies lag far behind their East Asian neighbors that have enjoyed rapid economic growth over several

\footnotetext{
${ }^{8}$ Devarajan and Nabi, 2006.
} 
decades (Figure-3 and Figure-4), and many have already acquired middle income status along with single digit poverty incidence.

Figure-3: Is High Growth in South Asia Sustainable? II: Obstacles that might become the next binding constraints; Insufficient power and port facilities

Difference in Infrastructure in South and East Asia

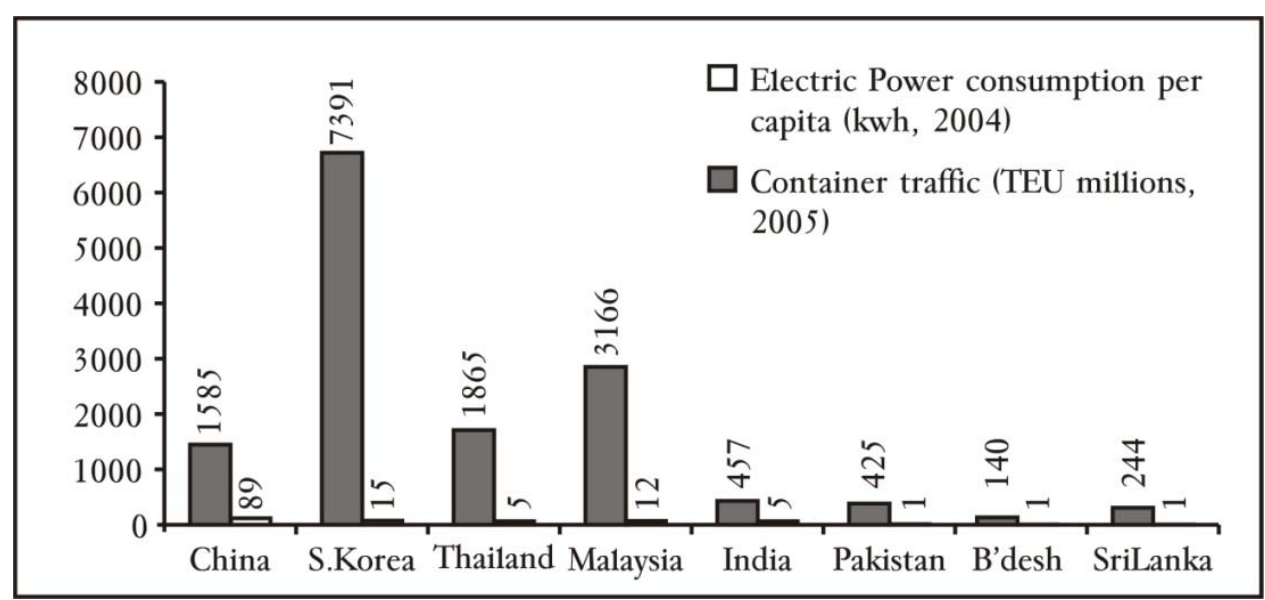

Figure-4: The Work Force Deficit

Trainability attributes of workers in South and East Asia

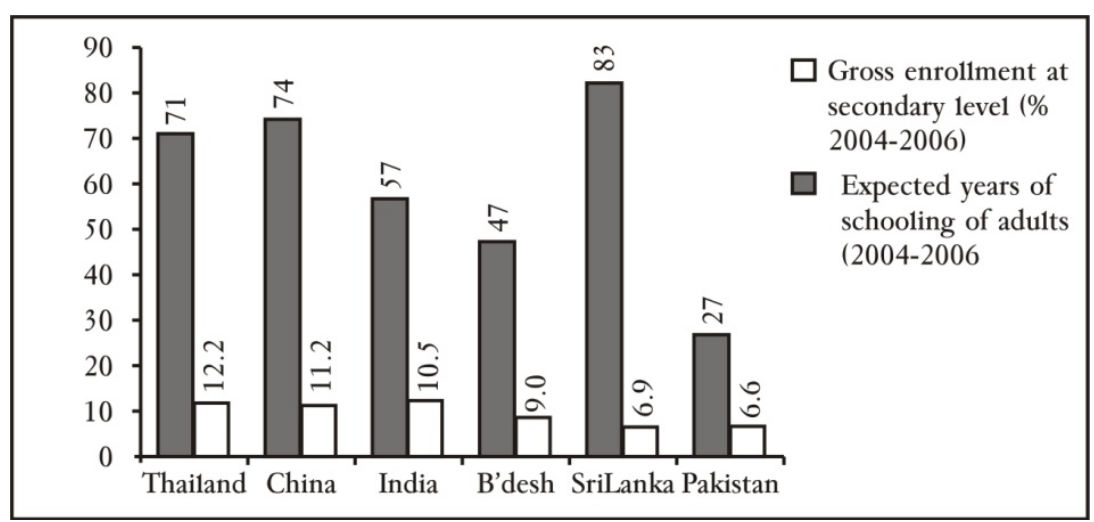

\section{Pakistan's Chronic Imbalance}

A notable feature of Pakistan's public expenditure patters is that outcomes, as measured in access to services, are heavily biased towards infrastructure compared to social services (Table-1). On six key social indicators viz. infant mortality rate, under five mortality rate, total fertility rate and primary school enrollment rate, outcomes are worse than other countries at 
similar levels of income. In the last five years (from 2000 to 2005), some outcomes, such as adult female literacy and primary school enrollment, have improved but others have deteriorated (infant and under 5 mortality rate). The total fertility rate is where it was five years earlier. Only secondary school enrollment has progressed sufficiently to match the income level.

Table-1: Access to Services Outcomes Relative to Others at Our Level of Per Capita Income

\begin{tabular}{|c|c|c|}
\hline Type of Service & $\begin{array}{c}\text { Performance } \\
\text { Relative to Others }\end{array}$ & Change in 2000-2005 \\
\hline \multicolumn{3}{|l|}{ Social Service } \\
\hline Infant Mortality Rate & Higher & Slight Deterioration \\
\hline Under 5 Mortality Rate & Higher & Slight Deterioration \\
\hline Total Fertility Rate & Higher & Unchanged \\
\hline Adult Female Literate Rate & Lower & Improvement \\
\hline Secondary School Enrollment & Same & Substantial Improvement \\
\hline Primary School Enrollment & Lower & Substantial Improvement \\
\hline \multicolumn{3}{|l|}{ Infrastructure } \\
\hline $\begin{array}{l}\text { Access to Improved Water } \\
\text { Sources }\end{array}$ & Higher & Slight Improvement \\
\hline Access to Improved Sanitation & Higher & Slight Deterioration \\
\hline Access to Electricity & Higher & Unchanged \\
\hline $\begin{array}{l}\text { Paved Roads as percentage of } \\
\text { Total }\end{array}$ & $\begin{array}{l}\text { Substantially } \\
\text { Higher }\end{array}$ & Improvement \\
\hline $\begin{array}{l}\text { Electricity Consumption (Kwh } \\
\text { Per Capita) }\end{array}$ & The Same & Slight Improvement \\
\hline Rural Access Index & Higher & N/A \\
\hline
\end{tabular}

Source: World Development Indicators (Various Years)

The story on physical infrastructure is just the opposite. On all six indicators, access to improved water, access to improved sanitization, access to electricity, paved roads and a composite rural access to services index, the outcomes are far better than those of countries at our level of income, and many indicators have improved in the last five years.

There are regional imbalances as well. Within Punjab (Figure-5), access to education is much better in the northern and central districts (gross primary enrollment rates of 108 and 92 respectively) than in the southern districts (60 percent). 
Figure 5: Regional inequality in Punjab

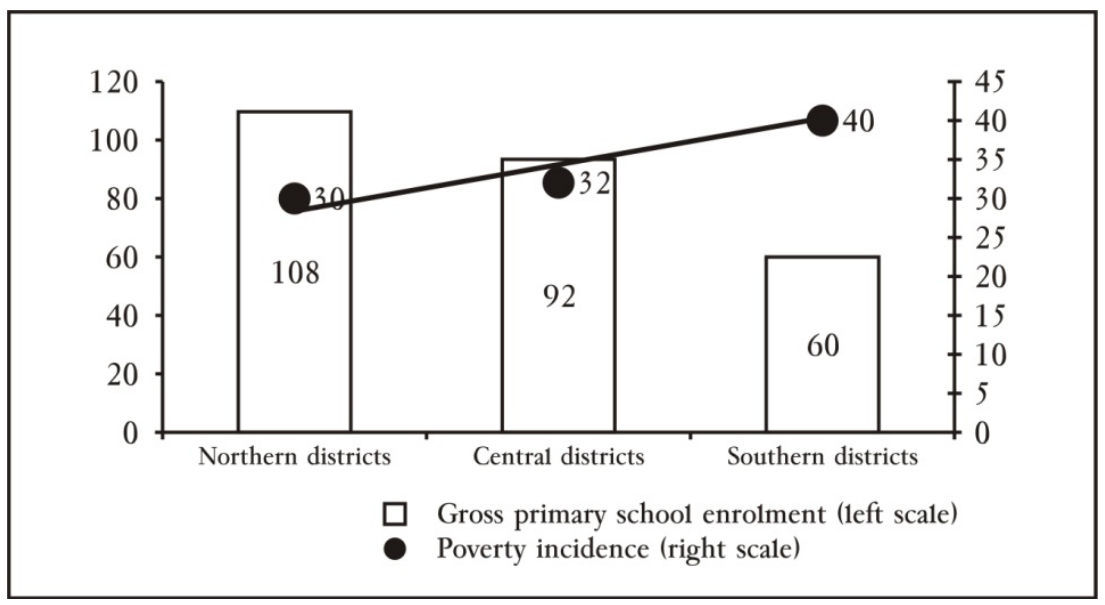

For sustained high and inclusive growth, the good performance on infrastructure outcomes needs to be sustained but outcomes in the social sectors have to improve significantly.

The Medium Term Development Framework (2005-10), seeks to redress these imbalances. The infrastructure investments (in energy, transport, water and telecoms) alone are projected at US\$ 37 billion. Redressing the social sector deficit will require an additional US\$ 7 billion. Together, these constitute a massive resource mobilization effort that will place a huge burden on a budget constrained by low revenues.

\section{Medium Term Priorities and the Boom and Bust Budget Cycles}

Even without accounting for the additional resource need, there is an enormous burden on the budget, which lies at the heart of the boom and bust budgetary cycles.

In a setting of low private savings and investment, the public investment program is expected to stimulate economic growth. The budget is also expected to fund national security concerns vis-à-vis a much larger and now rapidly growing adversary. Furthermore, the budget is also expected to respond to our perceived entitlements especially when it comes to the consumption of energy in the home, factories and transport. At the same time, aside from a small proportion of tax payers who carry an undue load of taxation, most citizens expect not to pay taxes. Thus the fiscal deficit, often substantially larger than the sustainable level of $3-4$ percent of GDP, is the Albatross that all finance ministers have to live with. 
A higher than sustainable fiscal deficit in normal times means that the budget cannot sustain directional shifts to the economy, such as greater expenditure in the poorer regions and build up reserves for contingencies due to internal and external shocks. Even expenditure outlays to bridge glaring social deficits in education and health cannot be sustained with the slightest tightening of the funding environment.

The burden on the budget is especially heavy in an environment of considerable vulnerability to external shocks. These shocks typically manifest themselves in terms of high energy prices and high interest rates on public debt. Occasionally, the external shock is triggered by decisions regarding national security (such as the 1998 nuclear explosion). Such shocks tighten the funding of deficits from external commercial sources and inflict painful adjustments.

The other implication of larger than sustainable fiscal deficits over a sustained period of time is that there is high dependency on foreign donors --- both bilateral and multilateral.

This is a source of discomfort since such official funding is conditional on support to major donors' geo-political concerns and development priorities.

The current fiscal crisis thus has a familiar ring (Figures 6-8). In the late 1990s and early 2000s, under the supervision of an IMF austerity program, measures for fiscal tightening were put in place that eventually bore results. In 2001-06, the fiscal deficit was maintained at sustainable levels of 4 percent or less. Subsidies (including greater pass through of energy prices and setting up mechanisms to do so on a regular basis) were cut back and defense spending was moderated, but the bulk of adjustment came via a steep reduction in public investment and continued underspending on the social sectors. Revenue performance continued to be anemic because of weak economic growth and poor collections. 
Figure-6: GDP Growth, Budget Deficit, and International Reserves

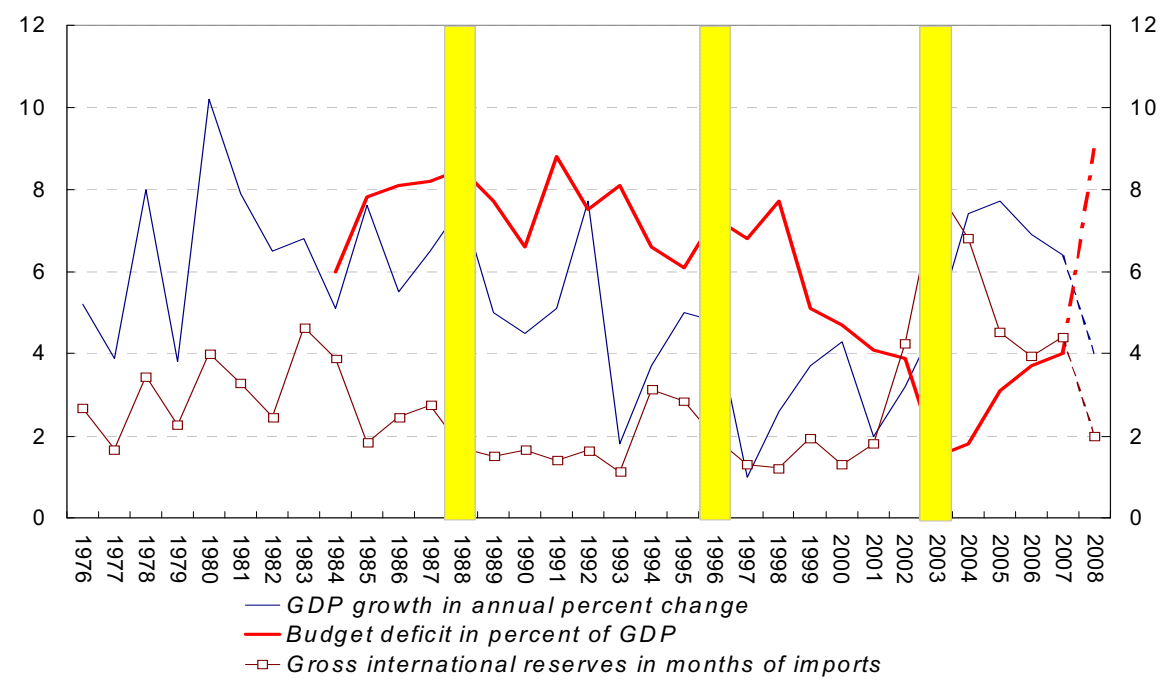

Figure-7: Crude Oil Prices and Interest Payments on Debt

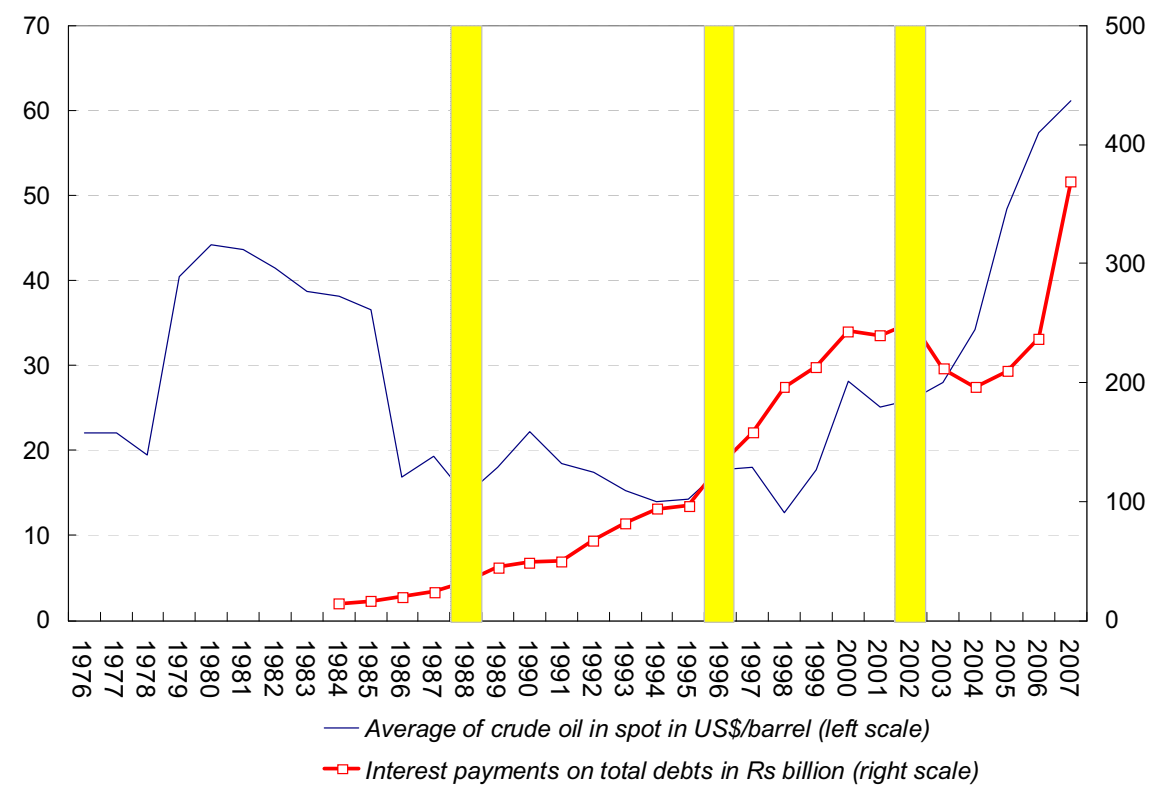


Figure-8: General Government and Social Expenditures

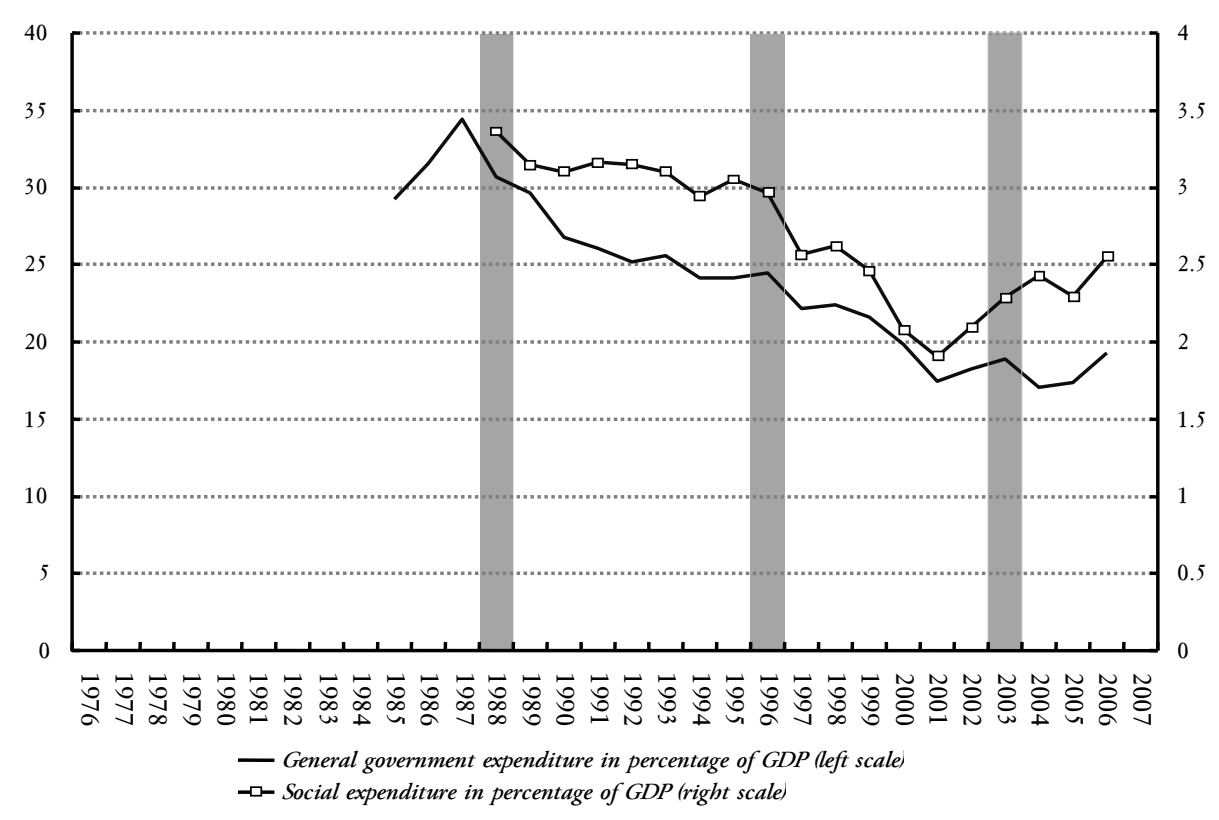

The generous debt forgiveness associated with the events of 2001 and direct budget support finally provided the fiscal space to increase both social spending as well as public investments. However, precariously perched on a razor's edge, at a barely sustainable 4 percent level, greater forbearance on energy price pass through and weak revenue performance, the budget was highly vulnerable to external shocks. These have come in the form of commodity price increases, especially oil and food, resulting in 2-3 percentage points of GDP additional subsidy. Combined with revenue shortfalls and underestimated interest payments on domestic debt, the deficit could well be 4-5 percentage points above the sustainable level.

Thus again, barely a year after achieving sustainable fiscal deficits, the budget is faced with massive adjustments threatening much needed expenditures in the social sector, critical infrastructure investment for sustained and inclusive growth.

How do we get out of the boom and bust budgetary cycle that threatens sustained high and inclusive economic growth? 


\section{The Design of Public Policy for Fiscal Prudence to Sustain High, Inclusive Growth}

Here is an illuminating anecdote from a prosperous Lahore neighborhood that has stimulated the analytical framework for this paper.

By the early 1990s, public space in this prosperous neighborhood had deteriorated sharply. Street lights barely worked, roads were potholed and the public park had gone to the dogs, literally. The residents of big houses on large lots had private gardens and did not care much for the public space. Fifteen years ago, one of the large houses was sold and converted into twenty town houses. The new residents needed their public space, which required additional expenditure above what the municipality could provide. They came together and devised the strategy of first improving public services (street lighting, guard petrol) and circulating their accounts to the residents. This was followed by a highly successful campaign at raising revenues, and the cycle was repeated. The neighborhood now is well lit, has orderly public space and a great public park. The government saw the success and chipped in with a road re-surfacing program.

Drawing upon this micro experience, which is similar to what happens worldwide on larger scale, this paper argues that putting the fiscal house in order requires addressing the design of public policy in the following areas:

1. Citizen ownership of public programs, which entails:

- Making expenditures credible via monitoring and evaluation of outcomes;

- Improving the quality of data and statistics for evidence based policy making;

2. Efficiency of public expenditure, which requires:

- Streamlining the project cycle at all tiers of the government;

- Seeking public private partnership in the provision of infrastructure and services;

3. Revenue collection; 


\section{D.1a: Citizen Ownership of Public Programs: Strengthen Monitoring and Evaluation}

Proper monitoring and evaluation of ongoing public programs helps ensure that expected outcomes are indeed being achieved. This enhances the credibility of programs and promotes citizen buy-in and willingness to pay either directly while using the service or indirectly via taxation. For example, the program of basic health units (BHUs) that was intended to provide basic health care (respiratory, skin and stomach related illnesses) to citizens quickly lost credibility as doctors did not show up, paramedical staff absconded and medicines were pilfered. Before long, the buildings became grain stores and animal shelters.

There is similar evidence of rampant teacher absenteeism (15-20 percent) in government run primary schools, which also get converted into storage spaces and animal shelters for the area's influential farmers. Such evidence of neglect and misappropriation does little to boost citizen credibility and willingness to pay taxes.

Following the establishments of district governments, some nazims have implemented imaginative programs along with strict monitoring to curb doctor absenteeism in BHUs. This rehabilitated the physical structures and the credibility of the program as evidenced in the throngs of rural poor in the rehabilitated BHUs.

Monitoring and evaluation of public programs contributes to improving the design of public programs through feedback loops. Learning and Educational Achievements in Punjab School (LEAPS), a study funded by the World Bank, Pomona College, USA, the Knowledge for Change Program and others, is a good example of using the latest evaluation techniques to inform the design of education expenditures in Pakistan. The study's objective was to assess the quality of education in public and private primary schools to inform the design of public policy as Pakistan gears up to incur large expenditures to increase primary school enrollment and completion rates.

The study is based on annual surveys in 112 Punjab villages (in 3 districts: Attock in the North, Faisalabad in the Center and Rahim Yar Khan in the South) between 2003 and 2007, covering 812 government and private schools, 12000 students, 5000 teachers, and 2000 households.

The findings of the study are that "government schools require twice the resources to educate a child compared to private schools --furthermore, children studying in private schools report higher test-scores in 
all subjects ---- partly because teachers exert greater effort", however, "access to private schools is not universal....private schools choose to locate themselves in richer villages and richer settlements within villages, limiting access to poor households....in contrast government schools ensure equal geographical access to all.... government reform should ensure that no child is left behind" in learning achievements.

This evaluation exercise has three important implications for improving the design of the program to achieve better outcomes of the large expected government expenditure in primary education. One is that the government has a critical role in providing information to households for taking informed decisions about school choice. Second, public schools should focus only on those areas where private schools will not go and also on programs that improve teacher quality and reduce teacher absenteeism. Third, the potential for various types of public/private partnerships in the provision of education should be explored for cost effective delivery of education to all.

Taking this approach to public programs in general will go a long way towards improving cost effectiveness of government programs, increase credibility with citizens and hence their willingness to pay taxes to fund government programs.

\section{D.1b: Citizen Ownership of Public Programs: Improve the Quality of Data and Statistics for Evidence Based Policy Making}

Achieving better policy outcomes requires evidence based policy making. In turn, that requires credible and timely public information of acceptable standards of quality. Moreover, statistics should be made available to the general public for independent analysis to inform public debate on issues of national concern. Along with an independent and competitive media, timely public information can go a long way in monitoring and evaluating policy outcomes and involving citizen voice in improving the design of programs. Indeed, one can argue that an independent statistical office is as vital a pillar of society as the judiciary and the media.

The recent controversy surrounding GDP growth and poverty reduction estimates underscores the importance of an independent statistical office. The contrast with India is instructive. The media in India and Pakistan are equally skeptical of their respective governments' statistical pronouncements but with a difference. If both governments announce GDP growth rates of 7 percent, the Indian media reports that it is more like 8 percent; the Pakistani media, on the other hand, reports the government 
numbers but editorials convey that growth is more like 6 percent or less. The Indian Statistical establishment, though in desperate need of modernization, is considered to be independent while Pakistan's statistical offices are considered to have lost their independence to Ms Rosy Scenario that haunts the corridors of the Federal Secretariat!

Such skepticism of government statistics is particularly troublesome as both investors and the media look to evidence-based due diligence and public debate.

Building statistical capacity along with strengthening freedom of information are thus central to modern economic management. A number of steps need to be taken to strengthen statistical capacity. These include:

- Setting up an independent Statistical Commission through an act of parliament headed by a person of reputation and supported by Commission members selected from among users of statistics in the public and private sectors including research establishments.

- The Commission, supported by best available expertise, formulating a strategy for improving the quality and timely availability of statistics.

- Improving the quality of provincial statistical offices by clarifying the relationship between the provincial and federal statistical offices including the latter's leadership role in capacity building and standardization of statistical norms. Provinces should prepare detailed plans for statistical improvements addressing manpower and hardware needs, and also website development to disseminate statistical information in a timely fashion.

- Being proactive in promoting evidence-based policy making through informed parliamentary oversight of policy implementation and by making data available to researchers and the media on information of public interest.

- Engaging with multi-lateral and bilateral donors to procure best international practice and funding for hardware and human capacity.

\footnotetext{
${ }^{9}$ Attributed to John Wall, former World Bank Country Director for Pakistan.
} 


\section{D.2a. Efficiency of Public Expenditure: Streamline the Project Cycle at All Tiers of the Government}

A central question to ask about public expenditures is whether citizens, as tax payers ---now or in the future--- are getting their money's worth. In other words how efficient is public expenditure? The evidence on this is mixed:

- At the aggregate macro level, Pakistan generally has lower Incremental Capital Output Ratios (ICORs) than most countries which can be interpreted to imply greater overall investment efficiency (both public an private) than most countries.

- Despite lower and frequently disrupted public investment in infrastructure, and lower expenditure on repair and maintenance, Pakistan's infrastructure outcomes are relatively good compared to countries at its level of income.

- Comparisons across countries for health and education sector-wide public expenditures show that public expenditure in Pakistan is relatively efficient; it ranks in the top $40^{\text {th }}-60^{\text {th }}$ percentile in health and top $50^{\text {th }}-80^{\text {th }}$ percentile in education. ${ }^{10}$

- At the micro-project level, however, there is room for greater efficiency, as elaborated below.

A recent study of 37 public projects illustrates the inefficiencies in public investment. On average, the projects took twice as long to complete as stated in the plan, and the cost over-run was $180 \%$. The over-run is greater for public infrastructure projects than social sector projects, and over-run increases when projects are executed jointly by national and subnational entities.

How inefficient this over-run is depends on how one measures it. It turns out the government departments tend to set a much higher bar of efficiency for their projects compared to international norms. Thus, on average, at planning stages, government agencies set highly ambitious completion time targets and compared to those, it takes twice as long and costs 80 percent more. However, compared to the more realistic international norms for project completion time, the time inefficiency declines to $60-70 \%$. This is still quite high! With the annual development

\footnotetext{
${ }^{10}$ Herrera and Pang, 2005.
} 
plan rising to $\$ 10$ - 12 billion, a time and cost efficiency improvement of 10 $20 \%$ would save $\$ 1-2$ billion.

It would take effort on three fronts to achieve greater efficiency at the project level. First, more due diligence at the project entry level is needed to select only the projects that have sorted out the site and land acquisition problems which is often the most important source of project delay. Second, a major effort is needed to improve cash flow over the project cycle. It can take up to 111 days for the funds to be released to the contractor (twice as long at lower tiers of government). Third, when multiple tiers of government are involved, project ownership needs to be clearly established and coordination across line ministries, the Planning Commission, the Finance Department and Accountant General Pakistan Revenues (AGPR) improved to avoid the end-fiscal year crush. Finally, the acute shortage of good project directors needs to addressed through training and mentoring programs (domestic and abroad) and greater use of private sector contractors ${ }^{11}$.

\section{D.2b. Efficiency of Public Expenditure: Public Private Partnership in the Provision of Infrastructure and Other Services}

Imagine a developing country that has scored the following firsts in harnessing public/private partnerships for investment in infrastructure: (i) attracted $\$ 5.3$ billion private investment (a quarter of which was foreign equity) by 20 Independent Power Producers to generate 4500 megawatts of power, including the gigantic single 1292 megawatt, US $\$ 1.6$ billion, project hailed by Euromoney as the "Deal of the Decade" for its size and complexity, (ii) succeeded in raising $\$ 3$ billion of foreign debt, from official sources and the international capital market, (iii) established a clear policy framework for executing power generation by private entities and its purchase by a public entity, including indexation of pricing to rising fuel costs and general inflation, (iv) acquired critical skills in the public sector to execute public-private partnerships on a large scale and of great complexity.

The country is Pakistan, the program is Independent Power production and the Deal of the Decade refers to the HUBCO deal. The years of accolades were 1994-1999. As a result of the successful program, Pakistan succeeded in raising power generation from 10,500 MW in 1993 to $17,399 \mathrm{MW}$ in 2000 which, given demand at the time, resulted in an exportable surplus.

\footnotetext{
${ }^{11}$ World Bank, 2007.
} 
Today, following rapid income growth in the last six years, Pakistan is again faced with peak period power shortage of 25 percent, and insufficient power may well become the binding constraint to growth as rising demand for power (expected with high growth rates) is unmatched by supply, thereby dampening demand and GDP growth. This situation is the result of a combination of several factors all rooted in mismanagement of this critical public investment program.

The scope of the investments needed to meet the forecasted demand of $20,160 \mathrm{MW}$ by 2010 and $44000 \mathrm{MW}$ by $2020^{12,13}$ is such that relying solely on the public sector to provide the additional power makes no sense. This is especially so in light of the fact that since 2000 only one additional power generation plant, the $1,450 \mathrm{MW}$ Ghazi Barotha plant, was commissioned in the public sector. Furthermore, large hydroelectric projects such as Kalabagh and even Bhasha dam face huge political challenges. In any case, following the recent increase in fuel costs, food prices and other claims on the budget, the fiscal space for large public projects has shrunk.

However, the rich experience gained from the success of publicprivate partnership for public investment in the power sector in the 1990s, both the initial euphoria and the subsequent sobering lessons from experience in dispute resolution and work outs, should be harnessed to attract private investment in public infrastructure generally and the power sector especially.

Some of the lessons learned from our own rich experience for forging successful public-private partnerships for investment in infrastructure include: (i) carry out sector-wide reforms to ensure cost effective delivery in the private sector (distribution efficiency and appropriate tariff policies are key), (ii) address the structure of public infrastructure providers to allow the market mechanism to operate as much as possible (in the power sector, unbundling of WAPDA to promote competition and associated efficiencies), (iii) put in place transparent, competitive, bidding procedures staggered over time to avoid information bottlenecks and suspicion of wheeling-dealing by political rivals, (iv) carry out thorough due diligence for contingent liabilities (especially for obligations denominated in foreign currency and (v) establish independent, well-staffed, regulatory bodies that allow for a smooth pass through of costs in the pricing of infrastructure services.

\footnotetext{
${ }^{12}$ WAPDA, 2006.

${ }^{13}$ Hydrocarbon Institute of Pakistan, 2005.
} 


\section{D.3. Strengthen Revenue Collection}

Pakistan's (consolidated) revenue mobilization at 14.9 percent of GDP is half that of developed countries, considerably lower than middle income countries (Malaysia 23\%, Mexico 22\%), and also does not compare well with countries at $\$ 1000$ income per capita (China $16 \%$, Indonesia $16.5 \%)$ or neighboring India (18.4\%). This pattern of lackluster revenue effort persists for total tax revenues and also for the principal tax instruments i.e. income and sales tax.

Moreover, revenue effort tracks GDP growth poorly. Between $1999 / 2000$ and 2002/03, when GDP growth was a lackluster 3.5 percent, revenue increased from 13.4 percent of GDP to 14.9 percent. But between 2002/03 and 2005/06, when average GDP growth recovered to an impressive 7 percent, there was virtually no revenue growth. Over the same period in India, average GDP growth of 7.3 percent was accompanied by average revenue growth of 2.5 percent of GDP.

Nearly a third of Pakistan's total revenue is accounted for by non-tax revenues and this ratio has changed little in the rapid growth period. This revenue structure partly accounts for the poor elasticity with respect to growth since the principal sources of non-tax revenue (charges for services provided by civil administration (35\%) and income from property and enterprises (29\%)) are not responsive to GDP growth.

One striking feature of Pakistan's tax system is that, despite the Federal structure of the country, provincial governments account for a tiny share $(5$ percent) of the consolidated tax revenue. The rest is collected by the Federation via the Federal (previously Central) Board of Revenue. A comparison of Indian and Pakistani Punjabs, both components of their respective federations, illustrates this (Figure-9). The share of own taxes to provincial/state GDP is a paltry 0.6 percent in Pakistan's Punjab, while it is 6.8 percent in the Indian Punjab. Thus provincial governments, closer to tax payers both in terms of service delivery as well as by sources of income generation, are engaged in efforts to increase tax revenues. Instead, they continue to be dependent on federal transfers to meet their expenditure needs. Pakistani Punjab's receives $4.6 \%$ of provincial GDP in transfers from the Center compared to the Indian Punjab (1.6 percent of State GDP). 
Figure-9: Own Revenue and Taxes of Indian and Pakistani Punjab

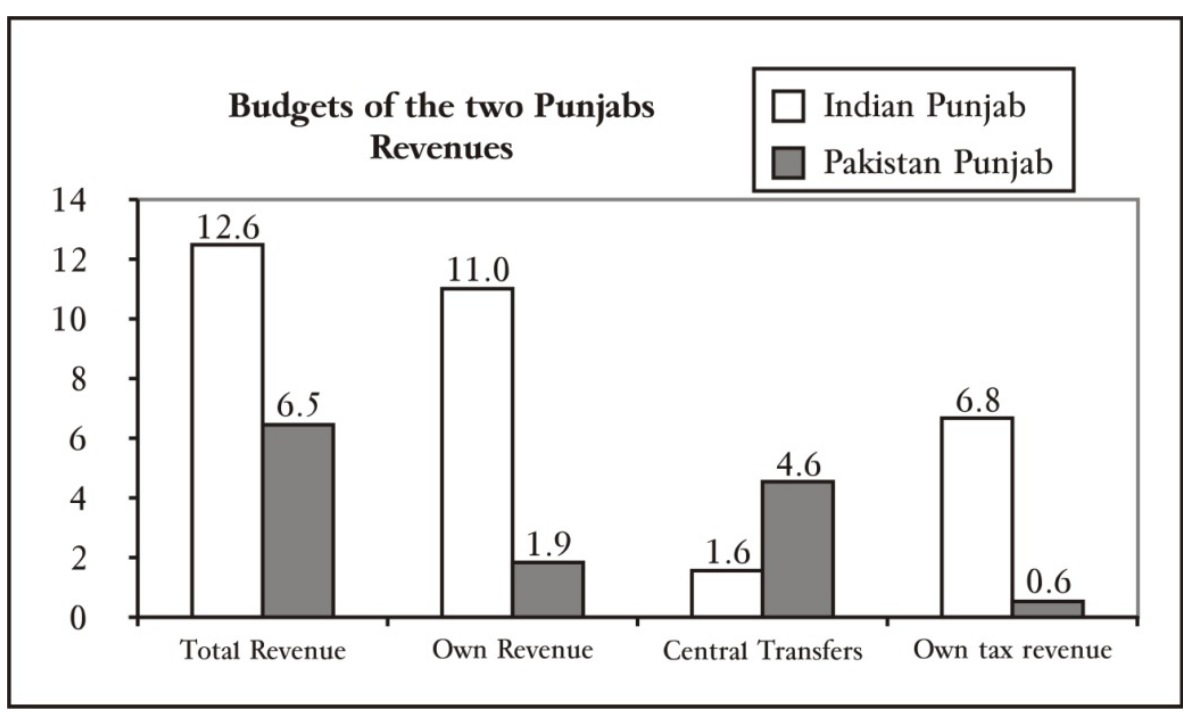

Weak revenue mobilization persists despite many attempts at policy and institutional reform. In 1986 and 1994, the Tax Commission brought out comprehensive reports and set the tax reform agenda rolling. Reduction in tariff rates began in the late 1980s, and a Generalized Sales Tax was introduced in 1990 to compensate for lower customs revenues and also to prepare for the VAT. The 1990s also saw the expansion of withholding taxes to increase tax collection along with the reduction and unification of direct tax rates. Introduction of full GST in VAT mode took place in 2000. The income tax ordinance was adopted in 2001 and self-assessment schemes were introduced as was the legislation for taxation of agricultural income. A comprehensive reform of tax administration was launched in 2004 with Word Bank assistance. Earlier in the 1990s, the momentum for reform was sustained via pressure and technical assistance from the IMF.

The impact of reforms on revenue generation was unimpressive. Overall revenue collection remained flat in the 1990s and 2000s (collections barely improved by 0.3 percent of GDP). This is on account of a number of factors: the 2001 income tax law relies mainly on voluntary compliance with little follow up in terms of audits; withholding taxes are mainly presumptive; the agricultural income tax has not been implemented; and the GST is riddled with exemptions.

However, there is an improvement in tax culture as seen in efforts to improve compliance through upgrading of staff skills, better audits and greater use of IT, more decentralization and sharper focus on large tax 
payers, improvement in the data base of registered tax payers and setting up an integrated tax management system.

A significant improvement is that the composition of taxes is evolving in the right direction. High import tariffs that distort production have come down from an average of 50 percent in 1995 to 15 percent in 2007. Also, excise duties and surcharges on gas and petroleum have been removed or reduced. Following these measures, the share of direct $(39 \%)$ and sales $(36 \%)$ taxes in total tax revenue has increased to 75 percent $(60 \%$ in 2000) while the share of excise $(9 \%)$ and customs (16\%) taxes has fallen. This bodes well for efficient resource allocation in the economy but has not done much for overall revenue collection. Following the reduction in tariffs between the 1990s and 2000s, revenue from customs duties fell from 4 percent of GDP to 1.5 percent. Similarly, phasing out of excise and surcharges on gas and petroleum resulted in revenue loss of 3.5 percent of GDP. This handing back of "bad" taxes (to the tune of 5.5 percent o GDP) to economic agents has not been compensated for by raising similar revenues through less distorting taxes on consumption and income.

But the full revenue generation potential, as shown in many examples from developing countries of successful tax reform, has not been realized.

Recognizing that potential, FBR has set some ambitious targets. It aims to increase tax collection on direct and sales taxes by 4.5 percentage points of GDP by $2016 / 17$ to off-set the revenue loss. This implies an annual increase of tax collection by 0.5 percent of GDP. This will happen only if there is progress on all key fronts viz. broadening the tax base of the "good" taxes, phasing out exemptions (estimates are that all told these cost 6.5 GDP in foregone tax revenue) and sharing the efficiencies with tax payers by lowering rates (and thereby motivating greater compliance).

\section{General Sales Tax}

Consumption, a proxy for the sales tax base, has grown rapidly in the last 5 years, while GST collection has fallen by 0.6 percent of GDP. This is largely because of exemptions. With fewer exemptions, and a tax rate of 15 percent rate, GST should yield between 6 to 7 percent of GDP in tax collection rather than the current 3.5 percent. To achieve these targets, a large part of the services sector that includes retail and wholesale trade, transport, construction, electricity, hotels, and restaurants, currently exempted, need to be brought into the tax net. 
Furthermore, zero rating of the textile chain, that constitutes a large part of manufacturing, has narrowed the tax base and has increased undocumented economic transactions. The textile chain needs to be brought into the tax net, and the problems of corruption and inefficiencies associated with duty drawbacks on export activities can be solved through streamlining procedures and information technology rather than exemptions.

The threshold of Rs 5 million turnover for GST registration is high by international standards and results in less than 2 percent of firms filing returns. This needs to be reduced to bring more firms into the tax base. India's successful experience with this tax can be useful in realizing the potential revenue increase from this tax instrument.

\section{Direct Taxes}

Exemptions (on pension income, income from federal securities, mutual funds and capital gains on assets other than immovable property) in the second schedule of income tax ordinance "cost" Rs 230 billion (nearly 3 percent of GDP) in foregone tax revenue and need to be reduced.

FBR collects income tax via withholding schemes rather than taxing wages and salaries directly. This lowers collections due to widespread evasion. With advances in information technology and better outreach, salaries and wages should be taxed directly.

Favorable treatment of small companies (lower tax rate of 20 percent as opposed to 35 percent for corporations) results in firms opting to remain small. This may lead to sub-optimal growth strategies and loss of potential tax revenue. This calls for equal treatment of firms and also for improving presumptive taxation of small businesses.

\section{Provincial Taxes}

Sub-national entities will have to play their proper role in improving revenue collection. The key features are effective taxation of services (already devolved to provinces) and expanding the property tax base. Given the huge recent increase in property values, it makes no sense for Lahore to suck in resources from small towns like Bhakkar, Muzaffargarh or Pakpattan. Provincial governments need to be motivated to improve tax administration (via IT, training and rational business practices) to enlarge their tax base. But this will require tackling the design of National Financial Commission award that, as currently structured, does not reward such effort. 


\section{E. Conclusion}

Even without the recent increase in commodity prices, the budget faced huge development challenges. Smoothing out the boom and bust cycle of the budget and allowing it to play the role of steering the economy towards sustained and stable growth will require a substantial mobilization of resources. This paper has argued that the need for additional revenues, and therefore an inordinately high tax burden, can be mitigated by using scare public resources efficiently and through public-private partnerships in infrastructure and social investments. It is also argued that greater citizen buy-in of public programs should be sought through proper monitoring and evaluation of programs and greater access to quality and timely information. This will encourage greater tax compliance and will help raise the revenues to meet the development challenges. 


\section{References}

Devarajan, S. and Nabi, I., 2006, "Economic Growth in South Asia; Promising, Unequalizing, Sustainable" Economics and Politics Weekly.

Herrera, S. and Pang, G., 2005, "Efficiency of Public Spending in Developing Countries: An Efficiency Frontier Approach," Policy Research Paper 3645, World Bank, Washington D.C.

Hydrocarbon Institute of Pakistan, 2005, Pakistan Energy Yearbook 2005, Islamabad.

Water and Power Development Authority (WAPDA), 2006, Presentation to the South Asia-Central Asia Electricity Trade conference, Islamabad.

World Bank, 2007, Pakistan Infrastructure Implementation Assessment Capacity, Washington D.C.

World Bank, World Development Indicators, Various Years, Washington D.C. 